\title{
INVESTIGATION ON COAGULATION EFFICIENCY OF POLYALUMINIUM SILICATE CHLORIDE (PASiC) COAGULANT
}

\author{
G. Gyawali* and A. Rajbhandari (Nyachhyon)* \\ *Central Department of Chemistry, Tribhuvan University, Nepal.
}

\begin{abstract}
Polyaluminium silicate chloride (PASiC) coagulant was synthesized by co-polymerization technique using aluminium salt and polysilicic acid at different $\mathrm{OH} / \mathrm{Al}$ and $\mathrm{Al} / \mathrm{Si}$ molar ratios. A synthetic turbid sample was used to investigate the coagulation efficiency of the prepared coagulant. After the coagulant dosing, flocculation time was set for 15 minutes followed by sedimentation for 20 minutes. High performance of coagulant was achieved at $2.5 \mathrm{molar}$ ratio of $\mathrm{OH} / \mathrm{Al}$ and 5 molar ratio of $\mathrm{Al} / \mathrm{Si}$ at the optimal $\mathrm{pH}$. The optimum $\mathrm{pH}$ range was found to be $7 \pm 0.5$. The effective coagulant dose for the efficient removal of turbidity was set as $2.5 \mathrm{mg} / \mathrm{L}$. As compared to conventional alum, PASiC has been found to be excellent inorganic polymeric coagulant for turbidity removal from water and residual aluminum was found to be minimal in comparison to conventional alum treatment. Hence, PASiC has proven the potentiality for the turbidity removal in water treatment over conventional alum.
\end{abstract}

Keywords: PASiC; Alum coagulation; Turbidity; Residual aluminium.

\section{INTRODUCTION}

Coagulation is a common process in the water treatment for destabilizing dissolved and colloidal impurities. Surface water generally contains suspended and colloidal solids from land erosion, decaying of vegetation, micro-organisms and color producing compounds. Coarser materials such as silt and sand can be eliminated to considerable extent by simple sedimentation but the finer particles must be chemically coagulated to produce larger flocs, so produced flocs aggregate which can be removed from the water in subsequent settling and filtration process. Aluminium based coagulant such as alum $\left[\mathrm{K}_{2} \mathrm{SO}_{4} \mathrm{Al}_{2}\left(\mathrm{SO}_{4}\right)_{3} .24 \mathrm{H}_{2} \mathrm{O}\right]$ or polyaluminium chloride (PAC) are commonly used for the removal of particulate colloidal and dissolved substances from water [1]. $\mathrm{Al}^{+3}$ coagulant is added directly to the water to be treated in the form of concentrated liquid where $\mathrm{Al}^{+3}$ ions hydrolyse rapidly with a very complex process [2] involving dissolution of salt, formation of hydroxy-oxides of the metal which may be highly charged and the entrapment of individual particles in the chemical precipitate form as-

$$
\begin{array}{ll}
\text { Dissolution - } \mathrm{Al}_{2}\left(\mathrm{SO}_{4}\right)_{3} 2 \mathrm{Al}\left(\mathrm{H}_{2} \mathrm{O}\right)_{6}{ }^{3+} & +3 \mathrm{SO}_{4}{ }^{2-}---------------(1) \\
\text { Hydrolysis - } \mathrm{Al}\left(\mathrm{H}_{2} \mathrm{O}\right)_{6}{ }^{3+}+\mathrm{H}_{2} \mathrm{O} & \mathrm{Al}\left(\mathrm{H}_{2} \mathrm{O}\right)_{5} \mathrm{OH}^{2+}+\mathrm{H}^{+} \\
\mathrm{Al}\left(\mathrm{H}_{2} \mathrm{O}\right)_{5} \mathrm{OH}^{2+}+\mathrm{H}_{2} \mathrm{O} & \mathrm{Al}\left(\mathrm{H}_{2} \mathrm{O}\right)_{4}(\mathrm{OH})_{2}^{+}+\mathrm{H}^{+} \\
\mathrm{Al}\left(\mathrm{H}_{2} \mathrm{O}\right)_{4}(\mathrm{OH})_{2}{ }^{+}+\mathrm{H}_{2} \mathrm{O} & \mathrm{Al}\left(\mathrm{H}_{2} \mathrm{O}\right)_{3}(\mathrm{OH})_{3}+\mathrm{H}^{+} \\
\mathrm{Al}\left(\mathrm{H}_{2} \mathrm{O}\right)_{3}(\mathrm{OH})_{3}+\mathrm{H}_{2} \mathrm{O} & \mathrm{Al}\left(\mathrm{H}_{2} \mathrm{O}\right)_{2}(\mathrm{OH})_{4}+\mathrm{H}^{+}
\end{array}
$$

This complex process is frequently represented by simplified equation as,

$$
\mathrm{Al}_{2}\left(\mathrm{SO}_{4}\right)_{3}+6 \mathrm{H}_{2} \mathrm{O}
$$$$
2 \mathrm{Al}(\mathrm{OH})_{3}+3 \mathrm{H}_{2} \mathrm{SO}_{4}
$$

The product of hydrolysis combine to form variety of species including $\mathrm{Al}_{6}(\mathrm{OH})_{15}{ }^{3+}, \mathrm{Al}_{7}(\mathrm{OH})_{17}{ }^{4+}, \mathrm{Al}_{8}(\mathrm{OH})_{20}{ }^{4+}$, $\mathrm{Al}_{13}(\mathrm{OH})_{34}{ }^{5+}$ etc. Then the polymeric species are formed. The effectiveness of coagulation depends upon both $\mathrm{pH}$ and applied concentration of coagulant. As free hydrogen ions released react with natural alkalinity hence the adequacy of natural alkalinity may be estimated from the following equation [3],

$\mathrm{Al}_{2}\left(\mathrm{SO}_{4}\right)_{3} \cdot 18 \mathrm{H}_{2} \mathrm{O}+3 \mathrm{Ca}\left(\mathrm{HCO}_{3}\right)_{2}=2 \mathrm{Al}(\mathrm{OH})_{3}+3 \mathrm{CaSO}_{4}+$ $18 \mathrm{H}_{2} \mathrm{O}+6 \mathrm{CO}_{2}$ (3)

Based on this reaction, $1 \mathrm{mg} / \mathrm{L}$ of alum with a molecular weight of 600 reacts with $0.5 \mathrm{mg} / \mathrm{L}$ natural alkalinity expressed as $\mathrm{CaCO}_{3}$ [4]. When water is treated with alum, it often leads to the residual aluminium problem in the treated water. The maximum recommended range of aluminium in drinking water by WHO is $0.05-0.2 \mathrm{mg} / \mathrm{L}$ [5]. The occurrence of aluminium in treated water has been considered to be an undesirable aspect of treatment practice [6] and it also gives rise to turbidity and may precipitate as $\mathrm{Al}(\mathrm{OH})_{3}$ [7].

It has been reported that both the resulting water quality and the rate of removal after sedimentation are greatly improved by the use of metal polysilicate complexes [8]. Recent studies showed that metal polysilicate coagulants have a higher efficiency towards removal of turbidity, color, COD and it also reduces the residual aluminium content [914]. Similarly, several studies have been made on the coagulation efficiency of polyaluminium chloride (PAC), polyaluminium sulphate (PAS) and polyaluminium ferric chloride [15-21]. Aluminium salt and activated silica, a sort of

Author for Correspondence: A. Rajbhandari (Nyachhyon), Central Department of Chemistry, Tribhuvan University, Nepal. Email: armila3@yahoo.com. 
polysilicate, can be combined under some conditions to prepare a new composite coagulant called polyaluminium silicate chloride (PASiC). Hence in this study, the investigation on the coagulation efficiency of laboratory prepared PASiC at different $\mathrm{pH}$ by taking different $\mathrm{OH} / \mathrm{Al}$ and $\mathrm{Al} / \mathrm{Si}$ molar ratios has been carried out. Aluminium sulphate (Alum) is one of the commonly used aluminium based coagulant in drinking water treatment and has been in operation for long. But, unfortunately, it leads to higher residual aluminium content in treated water. So, in this study a comparative study of coagulation performance of PASiC coagulant and conventional alum with their residual aluminium concentration after treatment has also been investigated.

\section{MATERIALS AND METHODS}

\section{Materials}

All the reagents and chemicals used in this experiment were used directly without any further purification. AR Potassium aluminium sulphate $\left[\mathrm{AlK}\left(\mathrm{SO}_{4}\right)_{2} \cdot 12 \mathrm{H}_{2} \mathrm{O}\right.$ ] was obtained from $\mathrm{BDH}$ and used for the preparation of stock aluminium solution. All the aluminium solution was then prepared by appropriate dilution. Buffer solution was prepared using sodium acetate trihydrate $\left[\mathrm{NaC}_{2} \mathrm{H}_{3} \mathrm{O}_{2} \cdot 3 \mathrm{H}_{2} \mathrm{O}\right.$; (LR grade, S.D fine)]. AR Erichrome Cyanine R indicator was purchased from CDH. Working solution of erichrome cyanine $\mathrm{R}$ indicator was then prepared by appropriate dilution. LR grade ethylenediaminetetraacetic acid (EDTA) $\left[\mathrm{CH}_{2} \mathrm{~N}\left(\mathrm{CH}_{2} \cdot \mathrm{COOH}\right) \mathrm{CH}_{2} \text {. COONa }\right)_{2} \cdot 2 \mathrm{H}_{2} \mathrm{O}$; was obtained from Qualigens. AR aluminium chloride hexahydrate $\left(\mathrm{AlCl}_{3} \cdot 6 \mathrm{H}_{2} \mathrm{O}\right)$ was purchased from Merck. LR sodium metasilicate [Na $\mathrm{Na}_{2} \mathrm{SiO}_{3} .9 \mathrm{H}_{2} \mathrm{O}$; ( CDH, Mol.wt. 284.2)] was used to prepare stock silica solution which is then used to prepare polysilicic acid.

\section{Preparation of sample kaolinite solution}

Local kaolinite was collected and air dried. It was grinded and was filtered through fine sieve (106 ìm) to get fine powder. About $4 \mathrm{gm}$ of the fine powder was dissolved in $2000 \mathrm{ml}$ of water and allowed to stand for 5 minutes. After 5 minutes, the supernatant liquid was taken as sample water.

\section{Preparation of Polyaluminium silicate chloride (PASiC) coagulant}

The $40 \mathrm{ml}$ of $(0.25 \mathrm{M})$ aluminium solutions [prepared from aluminium chloride hexahydrate $\left.\left(\mathrm{AlCl}_{3} \cdot 6 \mathrm{H}_{2} \mathrm{O}\right)\right]$ were taken in 12 separate beakers, then $2.1 \mathrm{ml}, 3.1 \mathrm{ml}$ and $6.3 \mathrm{ml}$ of $(0.3 \mathrm{M})$ polysilicic acid solution was added in each set of 4 beakers respectively to make corresponding 5, 10 and 15 molar ratio of Al/Si. Again, after five minutes of mixing, $20 \mathrm{ml}$, $30 \mathrm{ml}, 40 \mathrm{ml}$, and $50 \mathrm{ml}$ of $(0.5 \mathrm{M}) \mathrm{NaOH}$ solution was added drop wise to each set of 4 beakers to make 1 to $2.5 \mathrm{OH} / \mathrm{Al}$ molar ratios, respectively. Final volume was maintained to $100 \mathrm{ml}$ by adding water. Thus obtained final volume of $100 \mathrm{ml}$ in each beaker contained the different $\mathrm{Al} / \mathrm{Si}$ and $\mathrm{OH} / \mathrm{Al}$ molar ratios with constant aluminium concentration as shown in Table 1. This process of preparation of coagulant by polymerization is called co-polymerization technique.

\section{Methods}

\section{Coagulation method}

To study the coagulation performance and residual aluminium by using PASiC coagulant, a synthetic water sample of Kaolinite was used. The initial turbidity of which was 110 NTU at pH 7.3.

All the coagulation experiments were carried out using laboratory mechanical shaker. $200 \mathrm{ml}$ of water sample to be treated was taken in separate beakers. The coagulants having 3 different $\mathrm{Al} / \mathrm{Si}$ and $\mathrm{OH} / \mathrm{Al}$ molar ratios had been added to make $0.5 \mathrm{mg} / \mathrm{L}, 1.5 \mathrm{mg} / \mathrm{L}$ and $2.5 \mathrm{mg} / \mathrm{L}$ of aluminium concentration in respective beakers. Fast mixing was set for 5 minutes, followed by slow mixing for 15 minutes. Settlement time for the formation of floc was set to 20 minutes. After the settlement of floc particles, the supernatant liquid was withdrawn for the measurement of residual turbidity and residual aluminium content. To study the effect of $\mathrm{pH}$, the $\mathrm{pH}$ of sample was varied from 5 to 8 . In order to compare the coagulant efficiency and residual aluminium a parallel experiments were run using conventional alum (potassium aluminium sulphate). Percentage removal of turbidity was calculated by using the following equation,

$$
\% \text { Re } m \text { oval }=\frac{T-T_{2}}{T_{1}} X 100
$$

Where, $\quad \mathrm{T}_{1}=$ Initial turbidity and $\mathrm{T}_{2}=$ Final turbidity

Turbidity in solution was measured by HACH-2100 Turbidimeter. The supernatant solution after coagulant treatment was carefully taken for turbidity measurement. The aluminium content was determined by spectrophotometric technique using WPA-S 104 spectrophotometer, UK.

\section{RESULTS AND DISCUSSION}

\section{Spectrophotometric determination of aluminium}

Aluminium content in sample solution was determined spectrophotometrically using erichrome cyanine R method at pH 6, at $535 \mathrm{~nm}$ wavelength at room temperature. Fig. 1. shows a calibration curve for the determination of aluminium. The plot is linear and obeys Beer's law from 20 to 300 ìg/L aluminium concentration.

\section{Effect of pH}

It is known that $\mathrm{pH}$ is one of the factors that influence the gelation time. Different $\mathrm{pH}$ values ranging from 5 to 8 were selected to investigate the effect of $\mathrm{pH}$ on the turbidity removal and residual aluminium content in the treated water. The effective coagulant dose was selected as $2.5 \mathrm{mg} / \mathrm{L}$. A plot of percentage removal of turbidity versus $\mathrm{pH}$ is shown in Fig. 2. It shows that by increasing $\mathrm{pH}$, the turbidity removal percentage was found to increase initially around the neutral $\mathrm{pH}$ but afterwards, it started to decrease to some extent. This test showed that neutral $\mathrm{pH} 6.5$ to 7.5 is useful range of $\mathrm{pH}$ for turbidity removal. Moreover, $\mathrm{pH}$ has also got the 


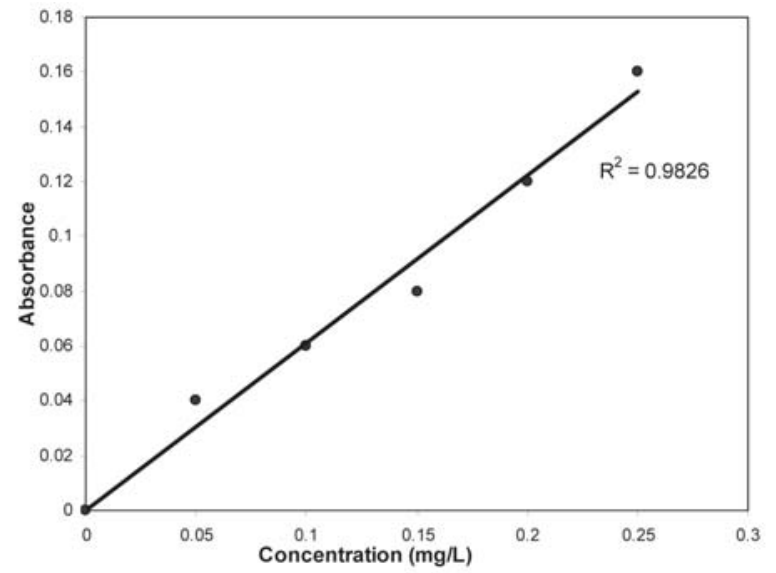

Fig.1: A plot of absorbance versus the concentration of Al in $\mathrm{mg} / \mathrm{L}$.

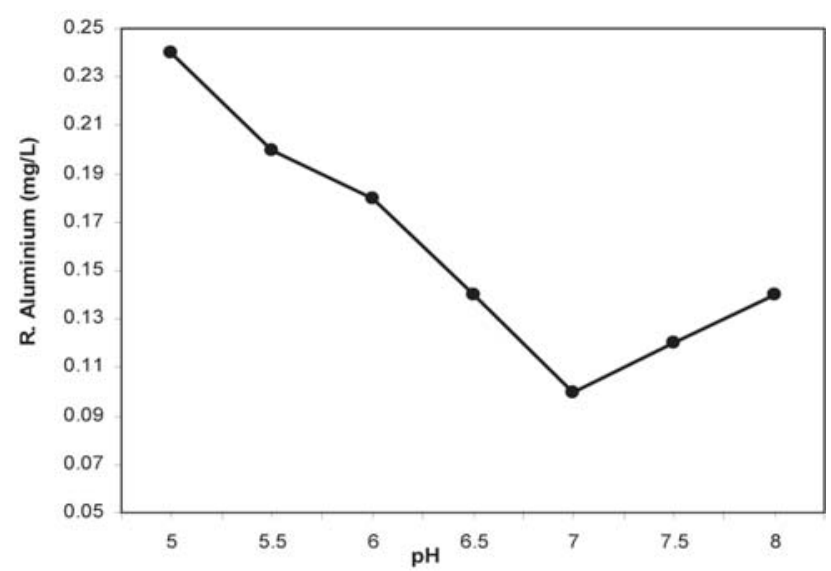

Fig. 3: Residual aluminium versus the $\mathrm{pH}($ at $\mathrm{Al} / \mathrm{Si}=5, \mathrm{OH} /$ $\mathrm{Al}=2.5$ and $\mathrm{PASiC}$ dose $=2.5 \mathrm{mg} / \mathrm{L}$ ).

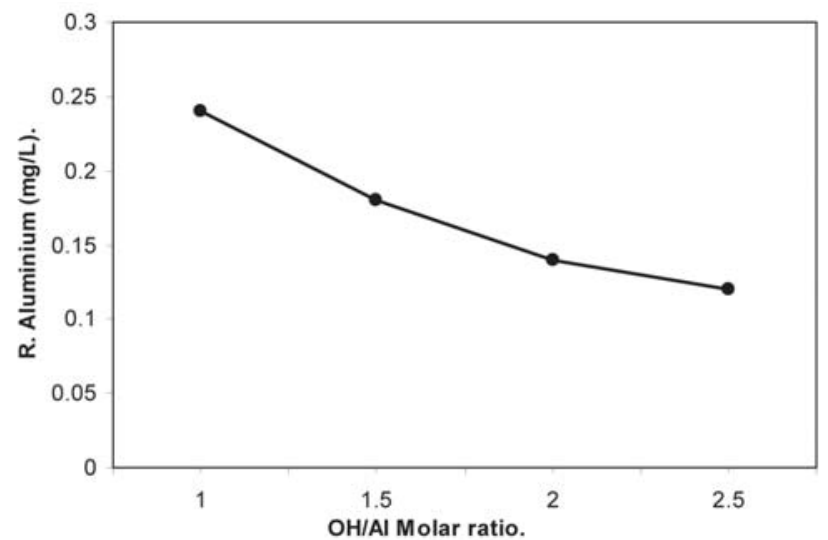

Fig. 5: Residual aluminium versus the the $\mathrm{OH} / \mathrm{Al}$ molar ratio (at $\mathrm{pH}=7, \mathrm{Al} / \mathrm{Si}=5$ and $\mathrm{PASiC}$ dose=2.5 $\mathrm{mg} / \mathrm{L}$ ).

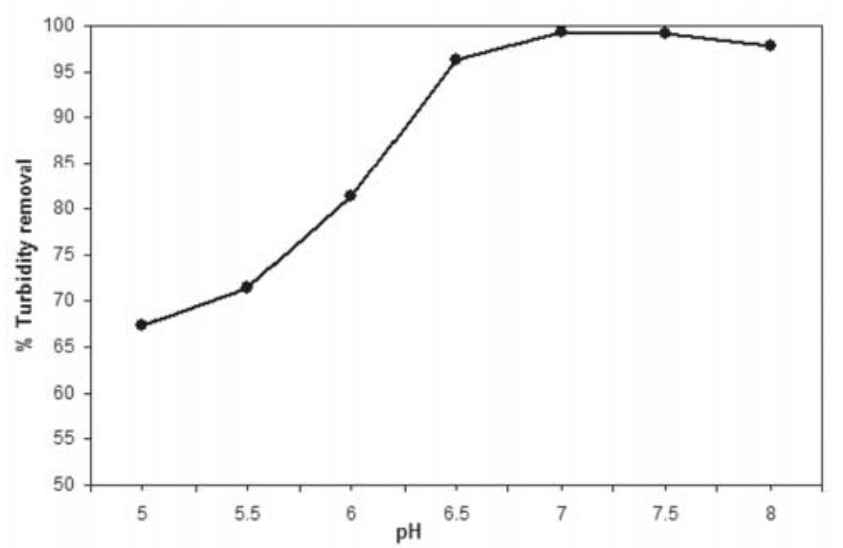

Fig. 2: Percentage turbidity removal versus the $\mathrm{pH}$ (at $\mathrm{Al} / \mathrm{Si}$ $=5, \mathrm{OH} / \mathrm{Al}=2.5$ and PASiC dose $=2.5 \mathrm{mg} / \mathrm{L}$ ).

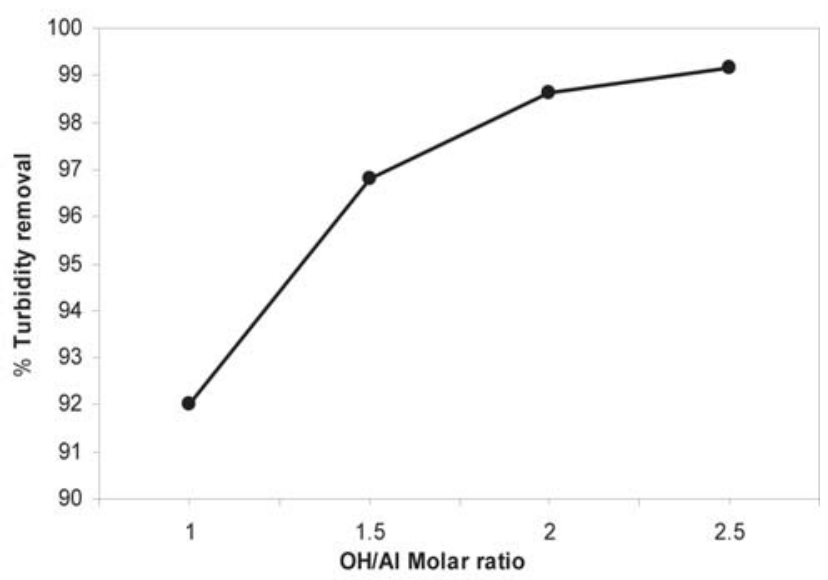

Fig. 4: Percentage Turbidity removal versus the OH/Al molar ratio (at $\mathrm{pH}=7, \mathrm{Al} / \mathrm{Si}=5$ and $\mathrm{PASiC}$ dose $=2.5 \mathrm{mg} / \mathrm{L}$ ).

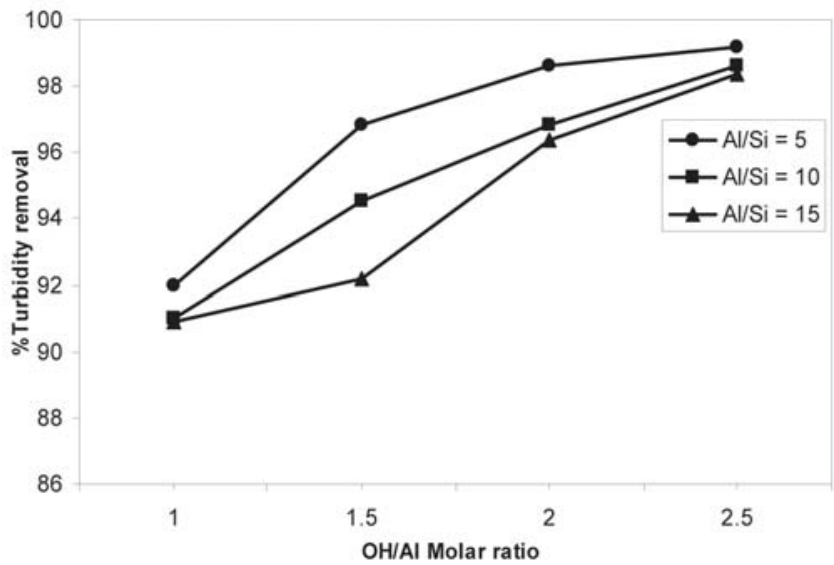

Fig. 6: Percentage turbidity removal at different Al/Si molar ratio (PASiC dose $=2.5 \mathrm{mg} / \mathrm{L})$. 


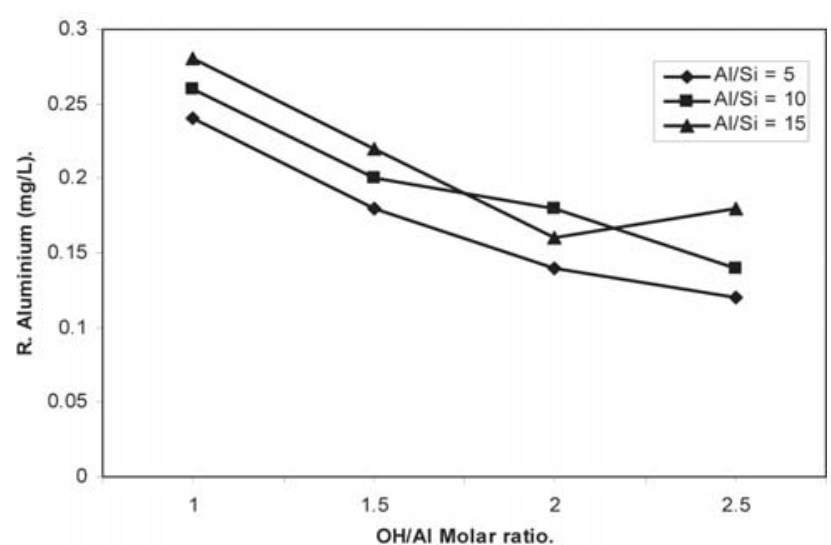

Fig. 7: Residual aluminium at different $\mathrm{Al} / \mathrm{Si}$ molar ratio ( PASiC dose $=2.5 \mathrm{mg} / \mathrm{L}$ ).

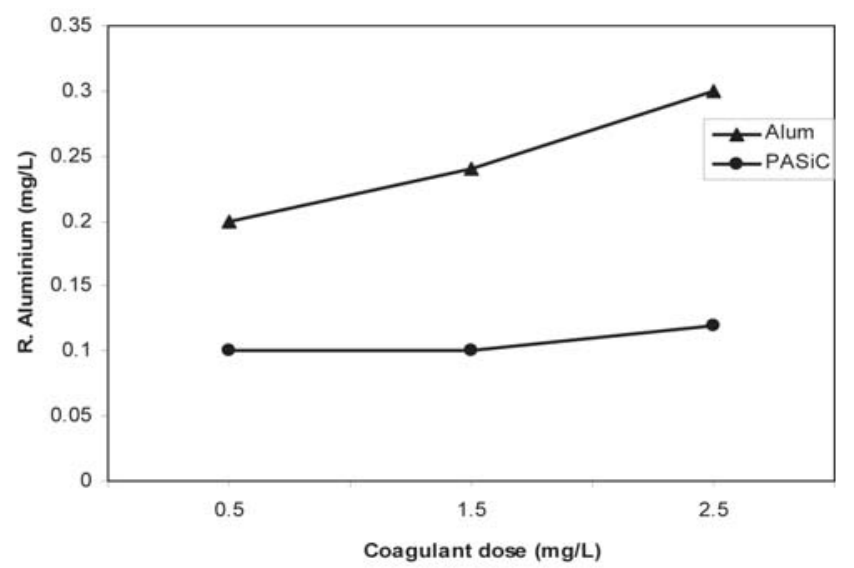

Fig. 9: Residual aluminium contents for conventional alum salt and PASiC coagulant as a function of variable coagulant dose.

considerable effect on residual aluminium content which is shown in Fig. 3. The residual aluminium content is relatively high in acidic $\mathrm{pH}$ (1 to 6) and alkaline $\mathrm{pH}$ (greater than 7.5). This may be due to the facts that the shifting of aluminium hydrolysis equilibrium increases the dissolved aluminium and not all of the aluminium particulates are absorbed by long chain polysilicate which are then removed by sedimentation process. The residual aluminium is low in neutral $\mathrm{pH}$ due to the formation of $\mathrm{Al}(\mathrm{OH})_{3}$ amorphous precipitates which is then removed by sedimentation. So, residual aluminium droped significantly around neutral $\mathrm{pH}$ while in $\mathrm{pH}>7.5$, due to the formation soluble $\mathrm{Al}(\mathrm{OH})_{4}^{-}$, the residual aluminium content increased in the solution.

\section{Effect of $\mathrm{OH} / \mathrm{Al}$ molar ratio}

The effect of $\mathrm{OH} / \mathrm{Al}$ molar ratio on the turbidity removal was investigated by varying the $\mathrm{OH}$ molar concentration in the coagulant while the concentration of aluminium was kept constant during the preparation of coagulant, so that $\mathrm{OH} / \mathrm{Al}$ molar ratio ranges from 1 to 2.5. All the experiments were conducted at low coagulant dose $(0.5 \mathrm{mg} / \mathrm{L})$, medium dose $(1.5 \mathrm{mg} / \mathrm{L})$ and high dose (2.5 mg/L) of coagulant, respectively. A plot of percentage turbidity removal versus the $\mathrm{OH} / \mathrm{Al}$

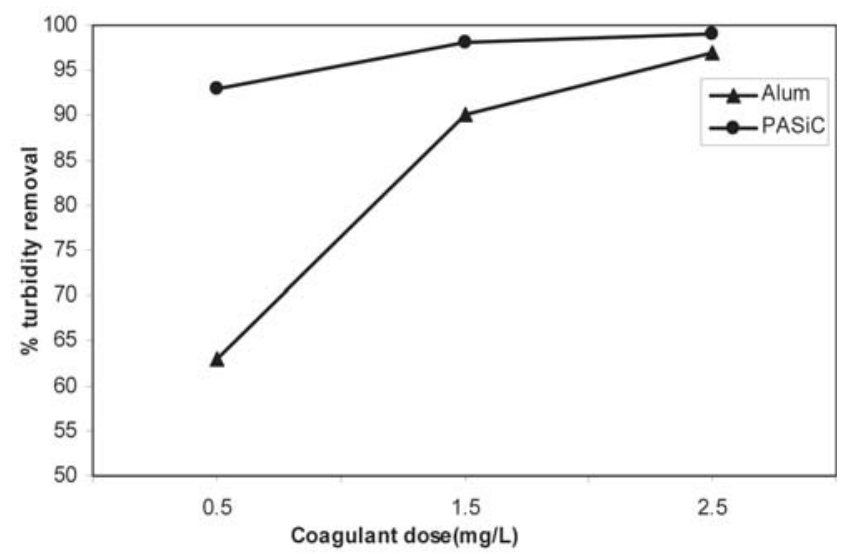

Fig. 8: Comparison of coagulation efficiency of conventional alum salt and PASiC coagulant as a function of variable coagulant dose.

Table.1: Preparation of PASiC having various $\mathrm{OH} / \mathrm{Al}$ and $\mathrm{Al} /$ Si molar ratios.

\begin{tabular}{ccccccc}
\hline $\begin{array}{c}\text { Coagulant } \\
\text { No. }\end{array}$ & $\begin{array}{c}\text { Vol. of } \\
\mathbf{0 . 2 5} \mathbf{M} \text { Al } \\
(\mathbf{m l})\end{array}$ & $\begin{array}{c}\text { Vol. of } \\
\mathbf{0 . 3 M} \mathbf{~ P S i A} \\
(\mathbf{m l})\end{array}$ & $\begin{array}{c}\text { Vol. of } \\
\mathbf{0 . 5} \mathbf{M} \\
\mathbf{N a O H}(\mathbf{m l})\end{array}$ & $\begin{array}{c}\text { Final } \\
\text { volume } \\
(\mathbf{m l})\end{array}$ & $\begin{array}{c}\mathbf{A l} / \mathbf{S i} \\
\mathbf{m o l a r} \\
\text { ratio }\end{array}$ & $\begin{array}{c}\mathbf{O H} / \mathbf{A l} \\
\mathbf{m o l a r} \\
\text { ratio }\end{array}$ \\
\hline 1 & 40 & 6.3 & 20 & 100 & 5 & 1 \\
2 & 40 & 6.3 & 30 & 100 & 5 & 1.5 \\
3 & 40 & 6.3 & 40 & 100 & 5 & 2 \\
4 & 40 & 6.3 & 50 & 100 & 5 & 2.5 \\
5 & 40 & 3.1 & 20 & 100 & 10 & 1 \\
6 & 40 & 3.1 & 30 & 100 & 10 & 1.5 \\
\hline 7 & 40 & 3.1 & 40 & 100 & 10 & 2.0 \\
8 & 40 & 3.1 & 50 & 100 & 10 & 2.5 \\
9 & 40 & 2.1 & 20 & 100 & 15 & 1 \\
10 & 40 & 2.1 & 30 & 100 & 15 & 1.5 \\
11 & 40 & 2.1 & 40 & 100 & 15 & 2.0 \\
12 & 40 & 2.1 & 50 & 100 & 15 & 2.5 \\
\hline
\end{tabular}

molar ratio is shown in Fig. 4. It revealed that increasing the $\mathrm{OH} / \mathrm{Al}$ molar ratio increases the percentage of turbidity removal. When the $\mathrm{OH} / \mathrm{Al}$ molar ratio is increased to 2.5, at $\mathrm{Al} / \mathrm{Si}$ ratio $=5$, the turbidity removal is found to be greater than $99 \%$. The residual aluminium content is found to be decreased with increasing $\mathrm{OH} / \mathrm{Al}$ molar ratio as shown in Fig. 5. At low $\mathrm{OH} / \mathrm{Al}$ ratio in coagulant, the poor coagulation performance and the higher residual aluminium content observed is mainly due to the existence of aluminium in the form of monomers and dimmers. When $\mathrm{OH} / \mathrm{Al}$ ratio is increased, the middle size aluminium products become predominant which improves the coagulation efficiency and reduces the residual aluminium content in the treated water. $\mathrm{Al}$ exists in trivalent oxidation state $\mathrm{Al}^{+3}$. Its electric charge and small ionic radius (0.51 ú) give $\mathrm{Al}^{+3}$ a strong polarizing effect on the adjacent atoms. Therefore, the element is too reactive to be found free in nature. As a strongly hydrolyzing element, $\mathrm{Al}$ is practically insoluble in the $\mathrm{pH}$ range of 6.5 to 8.5. The solubility is enhanced under acidic $\mathrm{pH}(\mathrm{pH}>6)$ or alkaline $\mathrm{pH}(\mathrm{pH}<8.5)$ conditions. The transformation of $\mathrm{Al}$ ions to $\mathrm{Al}(\mathrm{OH})_{--_{3}}$ is one of the mechanism for $\mathrm{Al}$ removal. Hydrolysis is the complex process involving several steps. 
Hence $\mathrm{OH} / \mathrm{Al}$ molar ratio is one of the important factors to be studied.

\section{Effect of $\mathrm{Al} / \mathrm{Si}$ molar ratio}

A plot of turbidity removal percentage with varying $\mathrm{Al} / \mathrm{Si}$ ratio is shown in Fig. 6. It showed that at a constant $\mathrm{pH}$ and constant $\mathrm{OH} / \mathrm{Al}$ ratio, lower value of $\mathrm{Al} / \mathrm{Si}$ ratio is favored for higher percentage of turbidity removal. Fig. 7 shows the residual aluminium content versus $\mathrm{Al} / \mathrm{Si}$ ratio which indicates that the lowering $\mathrm{Al} / \mathrm{Si}$ ratio decreased the residual aluminium content. This might be due the quicker and the larger development of the floc size as there is high content of polysilicate in the low $\mathrm{Al} / \mathrm{Si}$ molar ratio. Hence, there should be sufficient amount of silicates to effectively bind with free aluminium. It is obvious that the coagulant with a high molecular weight is more effective in improving their bridge formation capability for colloidal impurities, resulting in a more rapid floc development [14].

\section{Comparative study on coagulation performance of conventional alum and PASiC coagulant treatment.}

In Fig 8 and Fig. 9, percentage turbidity removal and residual aluminium content are plotted against coagulant dose of PASiC and conventional alum $\left(\mathrm{AlK}\left(\mathrm{SO}_{4}\right)_{2} \cdot 12 \mathrm{H}_{2} \mathrm{O}\right)$, respectively. Fig. 8 clearly shows that the percentage removal of turbidity by both coagulants is high when coagulant doses are increased but in Fig. 9, the residual aluminium content is found to be higher in high dosing of conventional alum, however, in PASiC coagulant, the residual aluminium is found to be less. These results are in tune with previously reported results of metal polysilicate coagulants [13].

\section{CONCLUSION}

The coagulation efficiency of laboratory prepared PASiC has been investigated. The lower residual aluminium content and higher turbidity removal efficiency were obtained by PASiC around neutral $\mathrm{pH}$. At higher and lower $\mathrm{pH}$, percentage removal of turbidity was found to be less but the residual aluminium content was also slightly high. The increase of $\mathrm{OH} / \mathrm{Al}$ molar ratio and decrease of $\mathrm{Al} / \mathrm{Si}$ molar ratio showed the better coagulation efficiency and minimum residual aluminium content of PASiC coagulant in comparison to conventional alum. In order to remove more than $95 \%$ of turbidity, the optimum $\mathrm{pH}$ range has been found to be $7.0 \pm$ $0.5, \mathrm{OH} / \mathrm{Al}$ molar ratio e" 2.5 and the $\mathrm{Al} / \mathrm{Si}$ molar ratio at $\mathrm{d}$ " 5 . Hence, PASiC can be the potential coagulant for the water treatment. Further study is needed for the investigation of flocculation time, floc size measurement, and the stability of coagulant.

\section{ACKNOWLEDGEMENT}

This research was supported by Central Department of Chemistry, Tribhuvan University, Nepal.

\section{REFERENCES}

1. Viraraghava, T. and Wimmer, C. H. 1988. Polyaluminium as an alternative to alum coagulation. A case study, Proc. of the Canadian society Civ. Engr. Annual conference, 480-498.

2. Weber, W. J. 1972. Jr. Physicochemical processes for water quality control. Wiley-Interscience. New York.

3. Steel, E.W. and McGhee, J. T. 1979. Water supply and sewerage, Fifth edition, McGraw Hill.

4. Hammer, M. J. and Hammer, M. J. Jr. 2003. Water and waste water technology, fourth edition, 239-240.

5. Federal register. 1991. Jan. 30, 56:20:3573.

6. Driscoll, C. T. and letterman, R. D. 1988. J. Environ Eng. Div ACSE, 114: 21-37.

7. Rahman, A. 1992. M.Sc. Thesis, State university of New york at Buffalo, NY.

8. Hasegawa, T., Hashimeto, K. and Onitsuka, T. 1991. Water sci. technol., 23: 1713-1722.

9. Arnold-smith, A. K. and Christie, R. M. 1992. Chemical water and waste water treatment, Springer, Berlin, 203-219.

10. Baoyu, G., Qinyan, y. and Bingjian, W. 2004. Acta Hydrochemica et Hydrobiologica, 32: 125-130.

11. Yue, Q. Y., Gao, B. Y. and Wang, B. J. 2003. J. Environ. Sci. 1: $69-74$

12. Gao, B., Yue, Q. and Wang, B. 2002. Chemosphere, 46: 809813.

13. Song, Y. H., Luan, Z. K. and Tang, H. X. 2003. Environ. Technol., 24: 319-327.

14. Gao, B.Y., Hahn, H. H. and Hoffmann, E. 2002. Water Res., 36: 3573-3581.

15. Malhotra, S. 1994. Affordable water supply and sanitation, $20^{\text {th }}$ WEDC conference, Colombo, Sri Lanka. 289-290.

16. Wang, D., Tang, H. and Gregory, J. 2002. J. Environ. Technol. 36: $1815-1820$.

17. Yani, G. and Li, S. 2000. Gaoxiao Jichu Kexue Xuebao, 13: 338-343.

18. Li, H., Addai-Mensah, J., Thomas, J. C. and Gerson, A. R. 2005. J. colloid interface Sci. 286: 511-519.

19. Gao, B., Yue, Q. and Miao, J., 2003. Water Sci. Technol. 47: 127-132.

20. Yang, H.Y., Cui, F.Y. and Zhao, Q. L. 2004. J. Zhejang Univ. Sci., 5: 721-726.

21. Wang, D. and Tang, H. 2001. Water Res., 35: 3418-3428. 